\title{
Report on the ODEPLAN/IDS Roundtable: La Via Chilena
}

\section{by Dudley Seers"}

At the invitation of the Chilean Government, IDS, in cooperation with the Chilean National Planning office (ODEPLAN) organised a round table conference on "The Chilean Road to Socialism", held in Santiago from 23 March - 1 April 1972. This conference was almost unique in the range of its participants. This was obviously true in terms of political zones (one does not often see Soviet and American citizens, or East and West Germans, together at non-official conferences in the social sciences); it was also true in the sense that it brought in a number of younger people not usually seen on the conference circuit. A third important feature was the fact that many Cnileans outside the Government attended, some of them distinctly critical of its policies.

The Round Table came at a most interesting moment, which will probably appear to the future historian as the end of the first phase of the Unidad Popular Government. The mining and banking sectors have been almost fully nationalised; a big step further has been taken in agrarian reform; a large part of manufacturing industry has been taken out of private hands. The combination of wage rises and price control has sharply shifted the distribution of income and helped to raise industrial output, employment and consumption, while regtraining inflation. Recently however, Congressional opposicion to nationalisation has hardened; the exchange reserves have largely disappeared (partly due to a fall in the price of copper), while heavy servicing charges are due on past debts; inventories have declined and investment in industrial equipment has been low; some consumer goods have become scarce. Sorne issues are now due for decision, and the way in which these decisions are made will shape the characteristics of the second phase.

* Dudley Seers, Director of IDS, has a long-held interest in Chilean development. He was Chief of the Survey Section, UN Economic Commission for Latin America from 1957-61 and has visited Chile frequently since then. 
The first two and a halz days of the Conference, with sessions, chaired alternately by Gonzalo Martner, the Mirister of Planning, and Emanuel de Kadt, were devoted to the problems inherited by the Government, the constitutional situation, the organisational changes made and the pattern of recent econoric developments. Highlights were speeches by President Aliende, the Ministers of Economics and Agriculture (Vuskovic and Chonchol respectively) the President of the National Defence Council (Eduardo Novoa) and the former Presidential candidate of the Christian Democrats (Radimiro Tomic).

The following two days were devoted to visits. The conference broke into 4 groups, visiting mines, factories, farms, and schools and hospitals. Participants were able to see conditions at first hand (and compare for example, private farms, 1 and reform settlements and the new 'land reform cencres')

The remaining 3 days, chaired by myself, were devoted to raising fundamental questions about what was happening and where it would lead to. Studies on the international situation facing Chile and on the experience of other socialist sociecies had been prepared at the request of IDS by experts from Europe and the U.S. These were dram on during this discussion.

After a sligitly discursive start on the role of the pubiic sector, during which the East Euroneans were brought into the discussion, there was a series of good sessions - divided into more clearly defined themes on 'participation', planning and the foreign exchange problem. Participants fron overseas had grasped enough of the situation to be able to make effective, often trenchant, contributions themselves, and most of them seemed to feel that with each hour they were getting new insights. There was some mumuring that officiais were being over-defensive, but in my view most government participanes were on the whole quite forthcoming, considering the somewhat tense political atmosphere.

In retrospect, that was probably the peak of the conference. Although there were many fascinating contributions in the final sessions, on income distribution and inflation, on 'political consciousness' and on the impeitinents to the "Via Chilena", there was some tendency to repetition. A certain weariness was also noticeable. It is tiring to fcllow a discussion partly in a foreign larguage (whether or not you rely on interpreters), day after day for more than a week, and although the 2 days of field trips had been mlanned as a break, we probably should have had one day comnletelv Iree. 
Still, there were no dropouts. The foreign participants and a large number of Chileans sat all through a final 5-hour session on a hot Good Friday afternoon. I did not sum up, and I think it would have been a mistake to attempt it. We were not there either to praise or to bury the "Via Chilena", but to understand it. Naturally coming from such a wide range of countries and with so many different political preconceptions, participants interpreted what they heard and saw in many different ways - and will need a little time to digest it all. The Chileans, I hope, will feel not only that some foreigners now do have a better understanding of the situation, but also that some of the comments have helped them themselves $t 0$ see a number of their problems in a new light.

The conference could not have taken place without the generous Einancial help of the Swedish International Development Authority, the Ford Foundation, and the Royal Institute of International Affairs. And the conference machinery functioned perfectly. A great deal of the logistic success was due to Adriana Peric and Ann Zammit, the conference officers from ODEPLAN and IDS respectively, both of whom had done months of preparatory work (and to David Lehmann who handled part of the work at the Sussex end).*

* I have discussed some of the substantive issues raised at the Conference in "Chile, is the road to Socialism blocked?", The World Today, May 1972, pp. 202 - 209. 


\section{IDS Communications}

A LIST OF SOME OTHER PUBIICATIUSS ON 'AID' A:" 'CHISA' BY PEOPLE ASSOCIATED WIIU IDS.

\section{Fundamental questions anj issues concurnirg An in gerera:}

Richard Jolly: "The Aic Felatisnship - SeElections on the Pearsor Report" fros the isumat gj" intemasioral Affairs, vol. XXIV no. 2, 1970.

Michael Lipton: "Forward Irom Pearsonism" IES FüZetin, December 1969

- Aid Allocation then Aid is Inadequate: Problems of the Non-implementation of the Pearson Report", forthcoming as chapter in book, ed. by Terry Byres, London.

Dudley Seers: "What are we trying to measure", in the joumal of Development Studies, 1972

- - The Total Relationship", chapter in Development in a Divided World, D. Seers and Leonard Joy, eds; Penguin, London 1971

-1.n- "Is Aid an Evasion of Development Problems?" Jourral of World Trade Low, November/December 1969 - Paul Streeten: "Overseas Development Policies under Labour." Chapter in mie I iboin Govemment's Econcmic Record, 19E4-70, Wilfrec Beckerman, ed., Duckworths, London, 1972.

Percy Selwyn: "Some Aspects of Aid to the Least Developed Countries" in Internatichal Deve Loment Review, Washington, September 1969

- Towards an International Welfare State"; IDS Bulletin, Dacember 1969.

Hans Singer: "Some Problems of Internaticnal Aid", u'ournal of World Trade Low, New York, March/April 1970

- International Aid to Developrent", in Assignment Children, UNICEF April-June 1971 December 1969 